\title{
A two-dimensional semantic analysis of falling in Modern Greek: A typological and corpus-based approach*
}

\section{T. Georgakopoulos}

National Research University Higher School of Economics, Moscow; athanasphil@gmail.com

\begin{abstract}
This paper investigates the semantic domain of FALLING in Modern Greek as it is reflected in its system of FALLING terms. Drawing from the frame-based methodology for lexical typology and based on a corpus-based analysis, it offers a description that covers two dimensions: an onomasiological and a semasiological. This two-dimensional analysis shows that the Modern Greek system should be classified as dominant, since the same lexeme, i.e. the Modern Greek equivalent of fall, is used to encode all four frames within this domain. It further reveals that the Modern Greek FaLLING system, albeit dominant, gives space to other encoding strategies to emerge. As a matter of fact, 13 additional motion verbs can be used to describe the various situation types. However, these verbs are confined within the boundaries of each frame. The very fact that each verb belongs to only one frame supports indirectly the existence of the four different frames. The analysis also indicates that the use of the basic lexeme is ruled out only in a few cases that involve the motion of a substance out of a container under the effect of gravity (parameter of fluidity) as well as the collapse of a floor or of an ice layer. Additionally, the study establishes the prototypical sense of the basic lexeme and allows the identification of certain collocation patterns associated with it. Finally, it offers the opportunity to cluster the senses of this basic verb into groups on the basis of their distributional (dis)similarity. To provide visual representations of the results, the current paper uses semantic maps, whereby nodes stand for both frames and micro-frames, as well as cluster hierarchies displayed as a dendrogram. Overall, the paper contributes to the typological analysis of the expression of FALLING. It offers insights on how the whole domain is carved up by the FALLING terms in a particular language and its results add to the body of typological literature investigating this domain.
\end{abstract}

Keywords: semantics of falling; frame-based methodology; lexical typology; onomasiology; semasiology; corpus-based; behavioral profile; Modern Greek.

* This article is an output of a research project implemented as part of the Basic Research Program at the National Research University Higher School of Economics (HSE University). I would like to thank Kiki Nikiforidou, Ekaterina Rakhilina, Daria Ryzhova, and one anonymous reviewer for commenting on drafts of the article. 


\section{Двусторонний семантический анализ}

\section{поля падения в новогреческом языке: \\ типологический и корпусный подход}

\section{Т. Георгакопулос}

Национальный исследовательский университет «Высшая школа экономики», Москва; athanasphil@gmail.com

Аннотация. В статье рассматриваются принципы лексикализации семантического поля падения в новогреческом языке. Глаголы падения рассматриваются с двух точек зрения: ономасиологической (с опорой на фреймовую анкету, разработанную Московской лексико-типологической группой) и семасиологической (на основе корпусного анализа). Такое двустороннее исследование показывает, что:

(а) греческая система глаголов падения является доминантной, поскольку выделяется лексема, использующаяся для описания всех фреймов поля; (б) имеется ряд лексем, конкурирующих с доминантной внутри каждого фрейма, не нарушая при этом границ между фреймами; (в) использование доминантной лексемы в зоне падения невозможно только в небольшом числе случаев, включающих ситуации перемещения субстанций из контейнера под воздействием силы тяжести, а также проваливание опорной поверхности (например, льда). Кроме того, анализ позволяет определить, какое значение доминантного глагола является для него прототипическим, выявить особенности сочетаемости доминантной лексемы и разбить ее значения на кластеры в зависимости от особенностей контекстов, в которых эти значения реализуются.

Ключевые слова: глаголы падения, фреймовый подход, лексическая типология, ономасиология, семасиология, новогреческий.

\section{Introduction}

This paper investigates the semantic domain of FALLING in Modern Greek (henceforth Greek) as it is reflected in its system of FALLING terms. By resorting to a variety of tools, namely dictionaries, corpora and dynamic visual stimuli, and by juxtaposing literature on lexical typology and corpus-based linguistics, it tries to $(a)$ identify the strategy that structures the semantic domain of FALLING in Greek. The important question in this respect is whether there is a single dominant verb covering all situations in the 
particular domain or there are two or more verbs; (b) provide an account of the semantics of the basic verb within the domain. To this end, the present study adopts both an onomasiological and a semasiological perspective (see Geeraerts, 2010). First, it lists all lexical items belonging to the domain of FALLING in Greek and shows which items can be used for which set of situations. In order to identify which expression matches which situation, the study uses a set of visual stimuli developed by the Moscow Lexical Typology Group. Second, it singles out the most important, i.e. the unmarked and most frequent (namely the one used in the majority of situations), verb in the domain and carries out a semasiological analysis. The method for this second analysis is dictionary- as well as corpus-based. As a result of performing such an analysis, not only direct, literal meanings - that refer to MOTION - but also figurative ones are taken into consideration. Although the semasiological part is not meant to be exhaustive, this two-dimensional analysis gives a semantically holistic view.

Specifically, the present study contributes to the typological analysis of the expression of FALLING. It offers insights on how the whole domain is carved up by the FALLING terms in a particular language and its results add to the body of typological literature investigating this domain (see [Reznikova, Vyrenkova 2015]; also the articles in this special issue). Given that languages demonstrate diversity in this domain, individual studies can shed light on the degree of this diversity. Additionally, the current paper employs a variety of methods including the use of visual recordings. However, implementing such tools as visual stimuli to elicit responses from native speakers suffers from a few shortcomings [Reznikova, Vyrenkova 2015]; [Rakhilina, Reznikova 2016]. What is important for our purposes is the fact that such tools are not appropriate for studying subjective experiences (e.g. mental activities). The semasiological step compensates for this shortcoming, as it takes into account semantic extensions of the FALLING meanings to other domains. Furthermore, the semasiological dimension provides quantitative information about the problem of prototypicality and allows the identification of certain collocation patterns associated with the basic FALLING verb in Greek. Finally, the semasiological analysis offers the opportunity to cluster the senses of this verb into groups on the basis of their distributional (dis)similarity.

The structure of the paper is as follows: Section 2 provides the theoretical background with a brief overview of the frame-based methodology. Section 3 gives the details about the different methodologies employed in the present paper. Section 4 presents the results of the onomasiological analysis 
and identifies the strategy that structures the semantic domain of FALLING in Greek. Section 5 completes the onomasiological analysis with a semasiological one, which gives an account of the semantics of the basic FALLING verb in Greek. Section 6 concludes.

\section{Theoretical background}

Drawing upon the frame-based methodology for lexical typology [Rakhilina, Reznikova 2014; 2016], I assume that a description of a semantic domain is only possible when one lists all frames relevant to this domain. In this context, frames are defined as sets of prototypical situations, as meaningful clusters of features, which are often closely intertwined. Frames are revealed by analyzing the sets of contexts in which they occur, which comes as a logical consequence of the basic premise of the approach that a lexeme's complete meaning is always contextual (see also Firth 1957; Apresjan 2000; among many others).

From the semantic point of view, within the general FALLING domain we may distinguish four main frames [Reznikova, Vyrenkova 2015]; [Rakhilina et al. 2019]:

(a) falling from an elevated surface (Frame 1)

(b) losing of vertical orientation (Frame 2)

(c) detachment (Frame 3)

(d) crashing down (Frame 4)

These frames can be thought of as etic comparative concepts (see [Haspelmath 2018: 87-88]), namely components of a comparative methodology that can be used for cross-linguistic generalizations. This is the kind of comparative concepts used, for example, in semantic map studies ([Haspelmath 2018]; on the notion of comparative concepts, see [Haspelmath 2010]; for an overview on semantic maps, see [Georgakopoulos, Polis 2018]; [Georgakopoulos 2019]).

All the aforementioned frames have a common semantic denominator. They indicate - by and large - the motion of an entity from a higher to a lower level, which is without control (and typically rapid). ${ }^{1}$ An additional

${ }^{1}$ In Concepticon, the concept set FALL is defined as "to descend in free fall due to the effect of gravity" [List et al. 2018]. 
important feature is the fact that the entity in motion should not be in contact with the surface while motion is in progress [Reznikova, Vyrenkova 2015: 6].

Languages differ from one another as to which strategies they use to encode these frames. In general, there are three types of lexical systems found in the languages of the world: dominant, distributed, and binary systems [Maisak, Rakhilina 2007]; [Reznikova, Vyrenkova 2015]. Dominant systems can use one lexeme for all situations. Distributed systems use a different lexeme for each situation (or at least more than two). Finally, binary systems carve up the semantic domain in a different way, as two separate lexemes are used for the different situations. As far as the FALLING domain is concerned, Reznikova and Vyrenkova (2015) report that dominant systems prevail in their sample. Before proceeding to the analysis, in which the Greek FALLING system will be classified, I provide a detailed description of the methods used in the present paper and a brief sketch of the Greek verbal system.

\section{Data and Methods}

\subsection{Introductory remarks}

The onomasiological analysis of the FALLING domain in Greek involves two steps. First, I checked previous studies on Greek motion verbs (mainly [Antonopoulou 1987]; also [Bassea-Bezantakou 1992]) in order to identify those verbs fitting the definition of FALLING given in Section 2. Second, using the visual stimuli developed by the Moscow Lexical Typology Group at the Higher School of Economics, I matched these verbs to the different situations depicted in the clips. Note, however, that for the different situations some additional verbs were used, which did not appear in the initial list of verbs found in the relevant studies. Finally, as far as the semasiological analysis is concerned, I consulted two Greek monolingual dictionaries [IMT 1998]; [Babiniotis 2002] as well as the Corpus of Greek Texts [Goutsos 2010].

\subsection{Identification of FALLING terms}

Antonopoulou (1987) provides taxonomies for the full set of Greek motion verbs. In these taxonomies, on the basis of certain criteria (e.g. unmarkedness), the most general verb in a set of verbs assumes the role of a taxonomic 
head and the remaining verbs in the set appear as subordinate categories. In the taxonomy of the FALLING conceptual area, the inclusive term is the lexeme péfto 'fall'. Three main subordinate categories for péfto are identified, which are distinguished according to $(a)$ whether the moving entity has control or not over the motion (parameter of "cause"; cf. category $2 v s$. category 1 respectively) and (b) whether the motion ends up into a liquid or not (parameter of "fluidity"; cf. category 3 vs. categories 1 and 2 respectively) [Antonopoulou 1987: 217]. Table 1 lists these lexemes classified in the three categories.

Table 1. Hyponyms of the basic Greek falling verb péfto (based on [Antonopoulou 1987: 217])

\begin{tabular}{|c|c|c|}
\hline $\begin{array}{l}\text { Category 1: Downward } \\
\text { motion due to gravity }\end{array}$ & \begin{tabular}{|c|}
$\begin{array}{c}\text { Category 2: Fall on sb. with } \\
\text { force }\end{array}$ \\
\end{tabular} & \begin{tabular}{|c|c|}
$\begin{array}{c}\text { Category 3: Downward } \\
\text { motion into liquid }\end{array}$ \\
\end{tabular} \\
\hline $\begin{array}{l}\text { katapipto } \\
\text { 'fall down' }\end{array}$ & $\begin{array}{l}\text { prospéfto } \\
\text { 'get on one's knees' }\end{array}$ & $\begin{array}{l}\text { vutáo } \\
\text { 'dive' }\end{array}$ \\
\hline $\begin{array}{l}\text { katrakiláo } \\
\text { 'roll down' }\end{array}$ & $\begin{array}{l}\text { ríxnome } \\
\text { 'throw oneself upon' }\end{array}$ & $\begin{array}{l}\text { kataðiome } \\
\text { 'dive' }\end{array}$ \\
\hline $\begin{array}{l}\text { kutruvaláo } \\
\text { 'roll down' }\end{array}$ & $\begin{array}{l}\text { Ximáo } \\
\text { 'fall violently' }\end{array}$ & \\
\hline $\begin{array}{l}\text { sorjázome } \\
\text { 'fall flat on the ground' }\end{array}$ & $\begin{array}{l}\text { enskipto } \\
\text { 'charge' }\end{array}$ & \\
\hline $\begin{array}{l}\text { katolisӨéno } \\
\text { 'slide down' }\end{array}$ & $\begin{array}{l}\text { ormáo } \\
\text { 'dash, fall violently on' }\end{array}$ & \\
\hline $\begin{array}{l}\text { gremizome } \\
\text { 'fall down / to pieces' }\end{array}$ & $\begin{array}{l}\text { eformó } \\
\text { 'dash, fall violently on' }\end{array}$ & \\
\hline $\begin{array}{l}\text { kataréo } \\
\text { 'collapse' }\end{array}$ & $\begin{array}{l}\text { epipipto } \\
\text { 'dash, fall violently on' }\end{array}$ & \\
\hline $\begin{array}{l}\text { tubáro } \\
\text { 'fall upside down, overturn' }\end{array}$ & $\begin{array}{l}\text { xínome } \\
\text { 'dash, fall violently on' }\end{array}$ & \\
\hline $\begin{array}{l}\text { anatrépome } \\
\text { 'fall upside down, overturn' }\end{array}$ & & \\
\hline
\end{tabular}

Although it is true that all these hyponyms belong to the FALLING domain and that in almost all cases the inclusive term péfto can replace ${ }^{2}-$ at least in some contexts - the subordinate term, not all lexemes listed here adhere to the definition given in Section 2. Specifically, all lexemes in the categories "Fall on sb. with force" and "Downward motion into liquid"

${ }^{2}$ For example, kataðiome 'dive', which cannot replace the general verb, is such an exception. 
should be excluded, since they involve a self-moving Trajector, ${ }^{3}$ who has control over his/ her action and whose motion is intentional. In the category "Downward motion due to gravity", the verbs katrakiláo, kutruvaláo, and katolisténo are not considered further, because the moving Agent is in contact with the surface while motion is in progress. In addition, tubáro and anatrépome were disregarded, because the motion does not take place from a higher to a lower point and because their use is limited to a specific class of LMs, i.e. vehicles. In Table 1, the verbs that fit the FALLING definition are colored grey. Interestingly, these are exactly the items - with the exception of katolis éno - that Antonopoulou (1987: 218) considers the closest to the general verb péfto.

Beyond the lexemes that Antonopoulou puts under the rubric of péfto, I also took into consideration items that appear in her general exhaustive list of Greek verbs of motion [Antonopoulou 1987: 326-331]. I checked the list for verbs that match the definition of FALLING adopted here. This process returned one additional verb, i.e. A xinete ${ }^{4}$ se C 'A is poured/spilled, flows to C'.

To sum up, the first step of the onomasiological procedure revealed six verbs that describe the uncontrolled, unintentional, and (typically) rapid movement of an entity from a higher to a lower point: péfto 'fall', katapipto 'fall down', sorjázome 'fall flat on the ground', gremizome 'fall down/ to pieces', kataréo 'collapse', and A xinete 'A is poured/ spilled, flows'.

\subsection{Video stimuli}

The visual stimuli consist of a set of 23 video clips showing different types of FaLLING. ${ }^{5}$ Table 2 presents the full list of the clips used (and catego-

${ }^{3}$ Following [Langacker 2008: 70], I use the term Trajector (henceforth TR) to refer to the most prominent participant within a profiled relationship and the term Landmark (henceforth LM) to refer to the entity that receives secondary focus in the relationship. In the domain of localization, the TR is the entity perceived as being located, whereas the LM is the location with respect to which the TR is located.

${ }^{4}$ Note that $A$ xinete se $C$ describes the unintentional motion, non-self propelled motion of an inanimate entity (e.g. of a liquid) and it thus contrasts with xinome 'dash, fall violently on', which refers to the controlled motion of an animate entity (although it is the same verb).

5 The different event types can be thought of as micro-frames in the sense of [Rakhilina, Reznikova 2016]. Micro-frames (a) are more specific than typical word meanings; (b) are often grouped similarly (across languages); and (c) are not expected to be expressed by a dedicated lexical unit [Rakhilina, Reznikova 2016: 107]. 
rizes these clips according to the frame they describe; see below). It should be noted that the stimuli appear in small capitals in order to distinguish them from the actual examples describing the different events. All FALLING events scenes involved different motion types which cover the four frames mentioned in Section 2: type A showed an entity falling from an elevated surface (event types $2,4,5,6,8,9,10,11,12,14,16,20,21)$. Type B showed an entity losing its vertical orientation (event types $7,17,19$ ). Type $\mathrm{C}$ consisted of events in which an entity is getting detached from a LM (event types $1,3,13,15$, 18). Type $D$ comprised events in which an entity falls down suddenly because of pressure or because of having no strength or support (event types 22, 23).

Table 2. Event types as represented in the video stimuli

\begin{tabular}{|c|c|}
\hline EVENT TYPE & Frame \\
\hline THE RING FALLS OFF THE FINGER & Frame 3 \\
\hline THE RAIN FALLS & Frame 1 \\
\hline THE HAT FALLS FROM SOMEBODY'S HEAD & Frame 3 \\
\hline THE LEAVES FALL FROM THE TREE & Frame 1 \\
\hline THE BALL FALLS FROM ABOVE IN FRONT OF SOMEBODY'S FEET & Frame 1 \\
\hline THE BOTTLE FALLS AND THE LIQUID IS POURED & Frame 1 \\
\hline THE TREE FALLS DOWN & Frame 2 \\
\hline THE WALLET FALLS FROM THE BAG & Frame 1 \\
\hline THE WATER FALLS INTO THE SEA & Frame 1 \\
\hline A SUBSTANCE IS POURED OUT OF A SEALED BAG (AND TO THE GROUND) & Frame 1 \\
\hline THE APPLE FALLS ONTO THE HEAD OF A MAN (FROM A TREE) & Frame 1 \\
\hline THE PLANE FALLS TO THE SEA & Frame 1 \\
\hline THE ROPE FALLS OFF THE NAIL (IT IS DETACHED FROM ITS BASE) & Frame 3 \\
\hline THE CANDLE MELTS (AND PART OF IT FALLS DOWN) & Frame 1 \\
\hline THE MAN'S HAIR FALL & Frame 3 \\
\hline THE MAN FALLS FROM THE BRANCH & Frame 1 \\
\hline A SHOTS B AND B FALLS TO THE GROUND & Frame 2 \\
\hline $\begin{array}{l}\text { (IT'S RAINING) PART OF A ROCK IS DETACHED FROM THE MOUNTAIN AND } \\
\text { FALLS INTO THE SEA }\end{array}$ & Frame 3 \\
\hline A HITS B (A WOMAN) AND B FALLS TO THE GROUND & Frame 2 \\
\hline THE TABLE OVERTURNS AND THE GLASSES FALL TO THE SAND & Frame 1 \\
\hline THE CHICK FALLS FROM THE NEST & Frame 1 \\
\hline THE ICE LAYER COLLAPSES (AND THE GIRL FALLS INTO THE WATER) & Frame 4 \\
\hline THE BUILDING COLLAPSES (E.G. AFTER AN EARTHQUAKE) & Frame 4 \\
\hline
\end{tabular}


Four native speakers (all linguists), who were aware of the goals of the study, provided descriptions for the whole set of the stimuli. The informants' responses showed variation with respect to style or with respect to the bulk of information they packaged in one sentence, but no variation was observed in the choice of the predicate(s) describing each event type, namely in the critical factor of the current study (see below in Section 4) .

\subsection{Corpus}

The data for the corpus analysis of the prototypical FALLING verb in Greek, i.e. péfto, come from the freely available Corpus of Greek Texts (CGT; see [Goutsos 2010] for a detailed description; cf. www.sek.edu.gr). The Corpus includes ca. 30 million words, but the size of the corpus used in the current study is ca. 14,500,000, since I did not take into account all text types of CGT (text types included in the current study: spoken mode: public speech; written mode: academic texts, literature, news, literature, and opinion articles). All the instances of péfto were first retrieved from CGT in the form of a concordance and this process resulted in 2,806 extractions. Second, for practical reasons (given that the annotation involved a wide range of variables; see Table 3), I did not examine the whole dataset, but I selected a representative random sample which corresponded to the $20 \%$ of the total extractions, i.e. 561 tokens. The random sorting of the tokens was performed by using the random number generator formula "=rand()" in MS Excel 2016. Following the methodology of Behavioral Profiles (see [Hanks 1996]; [Divjak, Gries 2006]; [Gries 2006; 2010]; [Berez, Gries 2009]; [Gries, Divjak 2009]; [Divjak 2010]; [Janda, Lyashevskaya 2011]; [Jansegers et al. 2015]; among others), each token was coded for certain semantic, morphological, and syntactic properties. The resulting spreadsheet consisted of 561 rows of occurrences of the verb and 18 annotated variables. Table 3 shows the variables (called ID tags after [Atkins 1987]) and their levels. Note that the coding schema included an additional variable, namely that of SENSE, which in fact is a paraphrase of to fall's meaning in the concordance line. The SENSE variable comprises 30 ID tag levels, which correspond to 30 different dictionary senses as identified in [IMT 1998] and [Babiniotis 2002]. The 561 tokens were categorized as belonging to one of these ID tag levels, i.e. senses. The ID tag levels of this variable are presented in Section 5. 
Table 3. ID tags and their levels

\begin{tabular}{|c|c|c|}
\hline Type of variable & Variable (ID tag) & ID tag level \\
\hline \multirow{5}{*}{ Morphological } & TENSE & non past, past \\
\hline & MODE & $\begin{array}{l}\text { indicative, subjunctive, imperative, } \\
\text { gerund }\end{array}$ \\
\hline & ASPECT & imperfective, perfective \\
\hline & NUMBER OF TRAJECTOR & singular, plural \\
\hline & NUMBER OF LANDMARK & singular, plural \\
\hline \multirow{5}{*}{ Syntactic } & SENTENCE TYPE & declarative, imperative, interrogative \\
\hline & CLAUSE TYPE & main, dependent \\
\hline & $\begin{array}{l}\text { PRESENCE OF A PREDICATIVE } \\
\text { NOUN OR ADJECTIVE }\end{array}$ & yes, no \\
\hline & $\begin{array}{l}\text { PRESENCE OF ADVERBIAL } \\
\text { ADJUNCT }\end{array}$ & yes, no \\
\hline & $\begin{array}{l}\text { TYPE OF ADVERBIAL } \\
\text { ADJUNCT }\end{array}$ & adverb, prepositional phrase \\
\hline \multirow{7}{*}{ Semantic } & USE & literal, non-literal \\
\hline & TRAJECTOR & animate, inanimate \\
\hline & LANDMARK & animate, inanimate \\
\hline & INANIMATE TRAJECTOR & concrete, non concrete \\
\hline & $\begin{array}{l}\text { CONCRETE INANIMATE } \\
\text { TRAJECTOR }\end{array}$ & $\begin{array}{l}\text { body part, man-made thing, } \\
\text { substance, group or organization, } \\
\text { vegetal entity, physical entity, } \\
\text { location, action, food }\end{array}$ \\
\hline & TYPE OF LANDMARK & $\begin{array}{l}\text { concrete, non concrete, } \\
\text { representation (e.g. unit } \\
\text { of measurement) }\end{array}$ \\
\hline & SEMANTICS OF THE PP & source, goal, source-goal, other \\
\hline
\end{tabular}

The different morphological ID tag levels give some hints about the verbal system of Greek. In Greek, each verb consists of a stem and inflectional ending, e.g. péft-o 'I fall/ I am falling'. In this example, the stem péft- encodes the main meaning of the verb, but the use of this stem also indicates that the verb is in the imperfective aspect. The ending - $o$ tells us that the verb is in the first singular of a non past tense in active voice. In general, the Greek verb is inflected for person $\left(1^{\text {st }}, 2^{\text {nd }}, 3^{\text {rd }}\right)$, number (singular, plural), tense (non past, past), aspect (imperfective, perfective), voice (active, passive), and mood (indicative, subjunctive, imperative) (cf. [Holton et al. 2012: 129]). Specifically for the category of mood, it has to be noted that imperative 
uses different verbal endings from indicative and subjunctive, while indicative and subjunctive are differentiated from each other with regard to the verbal particles which accompany the verb. For example, the subjunctive is expressed by the use of the particles $n a$ or as [Holton et al. 2012: 263-264].

After the detailed annotation, the next step was to convert Table 3 into a co-occurrence table that indicates which sense co-occurs with each feature (ID tag level). This is illustrated in Table 4, which shows such cross-tabulations for three senses (for two ID tags). Note that the percentages in the ID tag levels should sum up to 1 .

Table 4. Examples of Behavioral Profile vectors

\begin{tabular}{|l|l|c|c|c|c|}
\hline Variable (ID tag) & ID tag level & dash & enterState & fail & .. \\
\hline \multirow{2}{*}{ trajector } & animate & 0.87 & 0.95 & 0.08 & $\ldots$ \\
\cline { 2 - 6 } & inanimate & 0.13 & 0.05 & 0.92 & $\ldots$ \\
\hline \multirow{2}{*}{ tense } & non past & 0.41 & 0.25 & 0.17 & $\ldots$ \\
\cline { 2 - 6 } & past & 0.59 & 0.75 & 0.83 & $\ldots$ \\
\hline$\ldots$ & & & & & $\ldots$ \\
\hline
\end{tabular}

In Section 5, this Table including the Behavioral Profile vectors will be evaluated through the Hierarchical Agglomerative Clustering analysis, which assists the process of finding communities in data (for an explanation of the method, see [Divjak, Gries 2006]; [Divjak, Fieller 2014]; [Robinson 2014]; [Levshina 2015]). The statistical analyses and graphs in Section 5 were performed and created using the R statistical software package [R Core Team 2015].

\section{Onomasiological dimension: The domain of FALLING in Greek}

\subsection{Introductory remarks}

The first part of the analysis is devoted to the onomasiological dimension. In this part, the main goal is to identify the strategy that structures the semantic domain of FALLING in Greek. Table 5 shows which verbs can be used in which event type, based on the descriptions of the four native speakers. 
Table 5. Event types as represented in the video stimuli and the lexemes used by the informants

\begin{tabular}{|c|c|}
\hline EVENT TYPE & VERBS USED \\
\hline THE RING FALLS OFF THE FINGER & péfto, févgo, ylistráo \\
\hline THE RAIN FALLS & péfto \\
\hline THE HAT FALLS FROM SOMEBODY'S HEAD & péfto, févgo \\
\hline THE LEAVES FALL FROM THE TREE & péfto \\
\hline THE BALL FALLS FROM ABOVE IN FRONT OF SOMEBODY'S FEET & péfto \\
\hline THE BOTTLE FALLS AND THE LIQUID IS POURED & A xinete se $C$ \\
\hline THE TREE FALLS DOWN & péfto \\
\hline THE WALLET FALLS FROM THE BAG & péfto \\
\hline THE WATER FALLS INTO THE SEA & péfto, $A$ xinete se $C$ \\
\hline $\begin{array}{l}\text { A SUBSTANCE IS POURED OUT OF A SEALED BAG } \\
\text { (AND TO THE GROUND) }\end{array}$ & 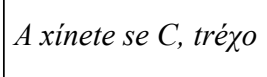 \\
\hline THE APPLE FALLS ONTO THE HEAD OF A MAN (FROM A TREE) & péfto \\
\hline THE PLANE FALLS TO THE SEA & péfto, katapípto \\
\hline $\begin{array}{l}\text { THE ROPE FALLS OFF THE NAIL } \\
\text { (IT IS DETACHED FROM ITS BASE) }\end{array}$ & $\begin{array}{l}\text { péfto, apokolóme, } \\
\text { févgo, ksekoláo }\end{array}$ \\
\hline THE CANDLE MELTS (AND PART OF IT FALLS DOWN) & stázo, péfto \\
\hline THE MAN'S HAIR FALL & 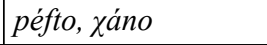 \\
\hline THE MAN FALLS FROM THE BRANCH & péfto \\
\hline A SHOTS B AND B FALLS TO THE GROUND & péfto, sorjázome \\
\hline $\begin{array}{l}\text { (IT'S RAINING) PART OF A ROCK IS DETACHED FROM THE } \\
\text { MOUNTAIN AND FALLS INTO THE SEA }\end{array}$ & péfto, apokolóme \\
\hline A HITS B (A WOMAN) AND B FALLS TO THE GROUND & péfto, sorjázome \\
\hline THE TABLE OVERTURNS AND THE GLASSES FALL TO THE SAND & péfto \\
\hline THE CHICK FALLS FROM THE NEST & péfto \\
\hline $\begin{array}{l}\text { THE ICE LAYER COLLAPSES } \\
\text { (AND THE GIRL FALLS INTO THE WATER) }\end{array}$ & kataréo \\
\hline THE BUILDING COLLAPSES (E.G. AFTER AN EARTHQUAKE) & $\begin{array}{l}\text { péfto, gremizome, } \\
\text { kataréo, } \\
\text { katakrimnizome }\end{array}$ \\
\hline
\end{tabular}

The first observation based on the data reported in Table 5 is that all six lexemes identified in the first step of the onomasiological process were used by the informants to describe the 23 event types. The tool used elicited, however, an additional eight verbs that are not included in the initial

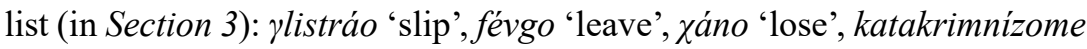


'crumble, collapse', apokolóme 'become detached', ksekoláo 'become de-

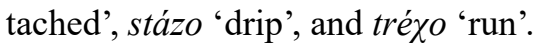

Most importantly, Table 5 provides a direct answer to the question as to which strategy structures the semantic domain of FALLING in Greek. Given that the same lexeme, namely péfto, can be used to encode all four frames, the Greek system is classified as dominant. It is quite striking that this general verb is used in 20 out of the 23 event types, the only exceptions being when a substance is poured out of a container (event types 6 , 10 ) and when the ice layer or a floor collapses (event type (22)). The usage of péfto in the four different frames is illustrated in the examples (1)-(4). The (a) parts in each example come from the native speakers' responses ${ }^{6}{ }^{6}$ whereas the (b) or (c) parts are examples collected from the corpus sample under investigation that match as closely as possible the event types of Table 5.

(1a) Péfti

(Frame 1; Event type 2)

fall.3SG.PRS rain.NOM.SG.F

'The rain falls'

(Frame 1; Event type 8)

$\begin{array}{llllll}\text { Péfti } & \text { apó } & \text { tin } & t s e ́ p i & t u & i \\ \text { fall.3sG.PRS } & \text { from } & \text { DEF.ACC.SG.F } & \text { pocket.ACC.SG.F } & \text { his.GEN } & \text { DEF.NOM.SG.F } \\ \text { taftótitá } & & t u & & \\ \text { ID_card.NOM.SG.F } & \text { his.GEN } & & & \end{array}$

'His ID card falls from his pocket' [CGT: WFBG10-0003]

(Frame 2; Event Type 7)

(2a)

$\begin{array}{lll}\text { To } & \text { dédro } & \text { épese } \\ \text { DEF.NOM.SG.M } & \text { tree.NOM.SG.N } & \text { fall.3sG.PST }\end{array}$

'The tree fell down'

(2b) $I$

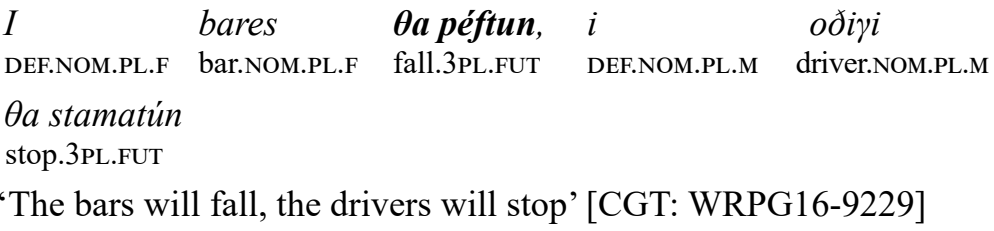

${ }^{6}$ In general, if there is no specific reference citing the source of the example, the example comes from the speakers' responses. 
(Frame 3; Event Type 15)

(3a) $\mathrm{Tu}$ épesan ta maljá him.GEN.CL fall.3PL.PST DEF.NOM.PL.N hair.NOM.PL.N

'His hair fell'

(Frame 3; Event Type 1)

$\begin{array}{lllll}\text { To } & \text { ðaxtiliði } & \text { épese } & \text { sti } & \text { stérna } \\ \text { DEF.NOM.SG.N } & \text { ring.NOM.SG.N } & \text { fall.3SG.PST } & \text { at:DEF.ACC.SG.F } & \text { tank.ACC.SG.F }\end{array}$

'The ring fell in the tank' [CGT: WABG13-0154]

(Frame 4; Event Type 23)

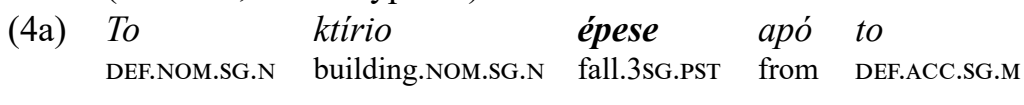
sizmó

earthquake.ACC.SG.M

$$
\begin{aligned}
& \text { [... se mia fási } i \\
& \text { at INDEF.ACC.SG.F point.ACC.SG.F DEF.NOM.SG.F }
\end{aligned}
$$

Examples (1a) and (1b) describe the typical situation in which an entity (the rain and the ID card, respectively) falls from a surface that is located at a higher point than the entity in motion (in (1a), this source of motion remains unexpressed, whereas in (1b) the LM bag fills in the source slot). Similarly, examples (2a) and (2b) show a prototypical case of an entity losing its vertical orientation: a tree falls down after being cut (2a) and a toll bar falls in order to prevent vehicles from passing through (2b). The detachment frame is exemplified in (3a) and (3b), which describe the loss of hair from the head (3a) and the fall of a ring off the finger (3b). Finally, in examples (4a) and (4b) péfto is used to refer to the collapse of a building.

Fig. 1 visualizes the frames encoded by péfto. This representation is akin to semantic maps, which comprise nodes standing for meanings (frames in our case). However, the representation in Fig. 1 differs from a typical (graph-based) semantic map in that there are no edges connecting the nodes and in that the arrangement of frames is not meaningful. The arrangement of the frames is arbitrary, as it is not the result of cross-linguistic comparison (cf. [Anderson 1982]; [Haspelmath 2003: 216-217]). Although one can build a preliminary semantic map for a given domain based on data from one 
language, which will later be tested against cross-linguistic data, there are certain conditions under which this is possible: (a) there should be different lexemes encoding different senses in the domain and $(b)$ these lexemes should exhibit polysemy within this domain. Both conditions should be satisfied. It is not possible to build such a map for the FALLING domain in Greek, because, although 14 motion verbs are used to describe the different event types, 13 out of 14 verbs do not transcend the boundaries of the frame in which each of them is attested. As a matter of fact, gremizome, kataréo, and katakrimnizome were found only in the 'crashing down' frame; apokolóme, ksekoláo,

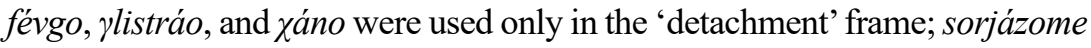
was used only in the 'losing of vertical orientation' frame; and xinete, tré $o$, ríxno, katapipto, and stázi were attested only in the 'falling from an elevated surface' frame. The very fact that each verb belongs to only one frame supports indirectly the existence of the four different frames. The only verb that exhibits polysemy within the FALLING domain is the general verb péfto, which however, as already pointed out, covers all frames. Thus, there is no principled way to decide on a certain configuration by relying on this verb's polysemy.

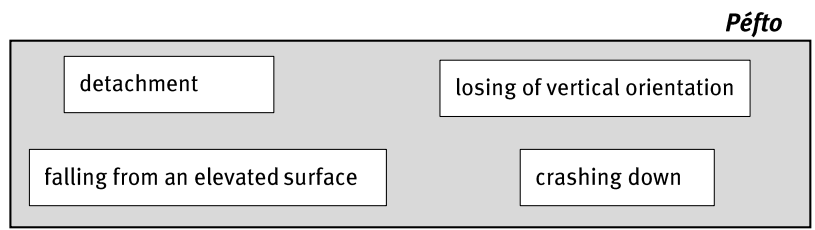

Figure 1. FALLING system in Greek: dominant/ The boundaries of péfto

In the following, I discuss mainly those cases in which a particular situation is lexicalized through a specialized lexeme as well as those instances in which along with the dominant verb alternative lexemes are also available. This discussion is structured on the basis of the four different frames.

\subsection{The 'falling from an elevated surface' frame}

In this frame, the dominant verb péfto is accessible in 11 out of the 13 event types. In the two situations in which this general verb is not available, the relevant property leading to the lexical opposition seems to be that of fluidity (a concept that refers to "powders, such as flour, and liquids' [Reznikova, Vyrenkova 2015]). When the event involves (a) a container (LM), (b) a contained substance in liquid or solid form (TR), and 
(c) a motion of the substance out of the container under the effect of gravity, then the verb xinete 'is poured/ spilled, flows' is normally used. In such cases, the 'type of object' moving, i.e. the substance, is profiled. Consider (5)-(6), in which the use of the dominant péfto is ruled out.

(Frame 1; Event type 6)

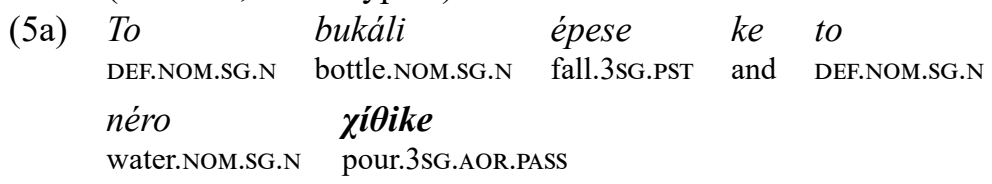

'The bottle fell and the water flowed out'

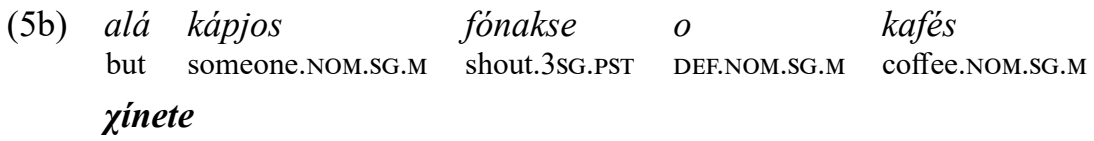
pour.3SG.PRS.PASS

'But someone shouted that the coffee is boiling over' [GCT: WFBG09-0001]

(Frame 1; Event type 10)

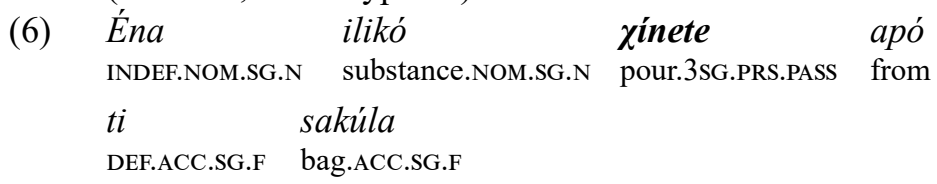

'A substance is poured out of the bag'

In some instances of fluidic motion, the dominant verb is also possible. This is illustrated in (7) and (8a), which describe the same situation but in a different way through the use of different verbs (respectively xinete and péfti). The different verbs provide an alternative way of framing the situation. Xinete evokes the frame of (Fluidic motion], whereas péfto evokes the frame of (Falling from an elevated surface). The latter imposes an interpretation in which both before and after the event the subject is in loose, unrestricted, uncontained form. Example (8b) from the GCT shows another situation in which the dominant verb can be employed to refer to fluidic motion.

(Frame 1; Event type 9)

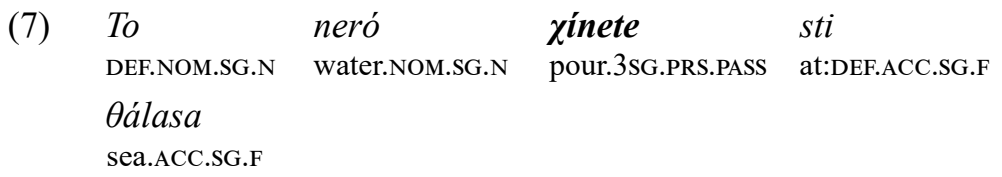

'The water is poured (in)to the sea' 
(8a) $\quad$ To

neró

péfti

sti

Oálasa

DEF.NOM.SG.N water.NOM.SG.N fall.3sG.PRS at:DEF.ACC.SG.F sea.ACC.SG.F

'The water falls (in)to the sea'

(8b) To

$$
\text { pira ke évala }
$$

ta

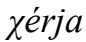

CL.ACC.N take.1SG.PST and put.1SG.PST DEF.ACC.PL.N hand.ACC.PL.N

$\begin{array}{lllllll}m u & \text { káto } & \text { apó } & \text { to } & \text { neró, } & p u & \text { arziká } \\ \text { my.GEN } & \text { under } & \text { from } & \text { DEF.ACC.SG.N } & \text { water.ACC.SG.N } & \text { REL } & \text { initially }\end{array}$

$\begin{array}{lccll}\text { épefte } & \text { kókin-o } & \text { san } & \text { éma } & \text { stin } \\ \text { fall.3SG.PST } & \text { red-NOM.SG.N } & \text { like } & \text { blood.NOM.SG.F } & \text { at:DEF.ACC.SG.F } \\ \text { porseláni } & t u & & \text { niptíra } & \\ \text { porcelain.ACC.SG.F } & \text { DEF.GEN.SG.M } & \text { washbasin.GEN.SG.M }\end{array}$

'I took it and put my hands under water, which initially was falling red like blood to the porcelain of the sink' [GCT: WFBG08-500]

The lexical opposition between péfto and xinete as a result of the parameter of fluidity poses a problem when it comes to the representation of the boundaries of the lexemes in semantic space. Specifically, a representation which would include the nuance 'substance falls out of a container' within the boundaries of péfto would have not been accurate. Thus, although the nodes on a map should be frames and not micro-frames [Rakhilina, Reznikova 2016: 107], Fig. 2 includes a (non exhaustive) list of the micro-frames belonging to the frame 'falling from an elevated surface'. In doing so, the difference between the two lexemes becomes apparent. The lexeme xinete encodes the three micro-frames 'the water falls into the sea', 'the bottle falls

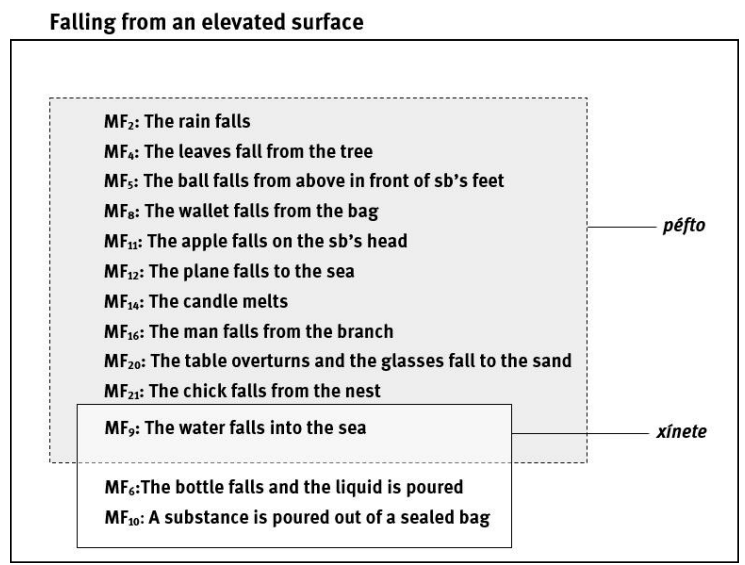

Figure 2. A micro-semantic map of the 'falling from an elevated surface' frame. The opposition between péfto and xínete (FALLING domain in Greek) 
and the liquid is poured' and 'a substance is poured out of a sealed bag', whereas péfto encodes only the micro-frame 'the water falls into the sea'.

Finally, in the context of falling from a great height (thus, when the relevant parameter is the source of motion) and when great speed is involved, the specialized verb katapipto ${ }^{7}$ can substitute for péfto [cf. Reznikova, Vyrenkova 2015]. Note that katapipto is highly marked for restricted use and high register. In addition, it is attested mostly in the past and in perfective aspect. Consider examples (9) and (10).

\section{(Frame 1; Event type 12)}

$\begin{array}{lllll}\text { To } & \text { aeropláno } & \begin{array}{l}\text { épese } \\ \text { fall.3SG.PST }\end{array} & \text { sti } & \text { at:DEf.ACC.SG.F } \\ \text { DEF.NOM.SG.N } & \text { sea.ACC.SG.F }\end{array}$

'The plane fell into the sea'

$\begin{array}{llll}\text { To } & \text { aeropláno } & \text { kat-épese } & \text { sti } \\ \text { DEF.NOM.SG.N } & \text { plane.NOM.SG.N } & \text { down-fall.3SG.PST } & \text { at:DEF.ACC.SG.F } \\ \text { Oálasa } & & & \\ \text { sea.ACC.SG.F } & & & \end{array}$

'The plane plummeted in the sea'

\subsection{The 'losing of vertical orientation' frame}

In this frame, the only relevant parameter that blocks the use of a verb and allows the use of another is that of Animacy. If the TR is inanimate, only péfto is possible (see examples (2a) and (2b)), but when the TR is animate both péfto and sorjázome ${ }^{8}$ 'fall flat on the ground' can be used. This is illustrated in (11) and (12).

\section{(Frame 2; event type 17)}

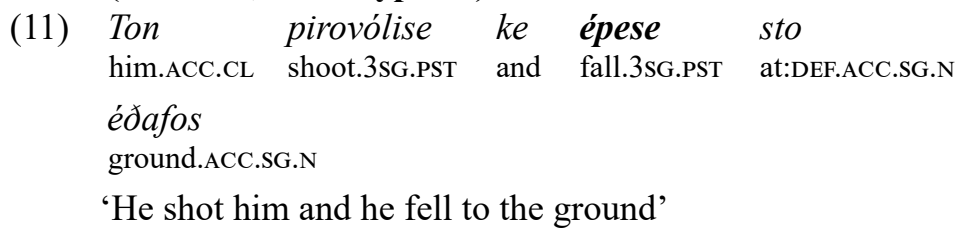

7 This verb is inherited from Ancient Greek (it is attested already in Homer). It consists of the prefix katá-, which refers to motion downwards, and the verb pipto, which in Ancient Greek denoted the motion from a higher to a lower point (the Ancient Greek form is piptō). In Modern Greek, the form pipto is found only in stereotypical expressions.

${ }^{8}$ The verb is etymologically related to the ancient Greek noun sōrós 'heap'. 
(12)

$\begin{array}{lllll}\begin{array}{l}\text { Ton } \\ \text { him.ACC.CL }\end{array} & \begin{array}{l}\text { pirovólise } \\ \text { shoot.3sG.PST }\end{array} & \begin{array}{l}\text { ke } \\ \text { and }\end{array} & \begin{array}{l}\text { sorjástike } \\ \text { collapse.3sG.PST.PASS }\end{array} & \begin{array}{l}\text { sto } \\ \text { at:DEF.ACC.SG.F }\end{array} \\ \text { éðafos } & & & \\ \text { ground.ACC.SG.N } & & & \end{array}$

'He shot him and he fell to the ground [lit. he collapsed to the ground]'

\subsection{The 'detachment' frame}

The falling down of TRs that are tightly attached to a LM is encoded by means of the general FALLING verb, as in (13)-(17).

\section{(Frame 3; event type 1)}

$\begin{array}{llll}T u & \text { épese } & \text { to } & \text { ðaxtiliði } \\ \text { him.GEN.CL } & \text { fall.3SG.PST } & \text { DEF.NOM.SG.N } & \text { ring.NOM.SG.N }\end{array}$

Lit. 'The ring fell from him'

\section{(Frame 3; event type 3)}

(14)
$\mathrm{Tu}$
épese
to
kapélo
him.GEN.CL fall.3SG.PST DEF.NOM.SG.N hat.NOM.SG.N

Lit. 'The hat fell from him'

\section{(Frame 3; event type 13)}

$(15)$

\begin{tabular}{|c|c|c|c|c|}
\hline To & sxiní & épese & apó & $t i$ \\
\hline DEF.NOM.SG.N & rope.NOM.SG.N & fall.3sG.PST & from & DEF.ACC.SG.F \\
\hline vási & $t u$ & & & \\
\hline base.ACC.SG.F & POSS.GEN & & & \\
\hline
\end{tabular}

\section{(Frame 3; event type 15)}

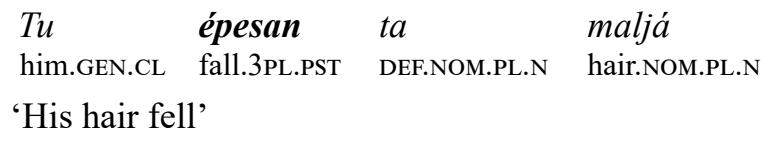

\section{(Frame 3; event type 18)}

\begin{tabular}{|c|c|c|c|c|}
\hline$O$ & vráqos & épese & $s t i$ & Oálasa \\
\hline $\begin{array}{l}\text { DEF.NOM.SG.M } \\
\text { 'The rock fel }\end{array}$ & rock.NOM.SG.M & fall.3SG.PST & at:DEF.ACC.SG.F & sea.ACC.SG \\
\hline
\end{tabular}

${ }^{9} \mathrm{Cf}$. the unacceptable sentence *To dédro sorjástike sto éðafos (lit. 'The tree collapsed to the ground'). 
It is worth noting that all situations in this frame allow also for different construals. Specifically, instead of being construed as motion events that include a TR performing a downward motion as a result of a detachment, these situations can be conceptualized as genuine processes of detachment, in which the downward motion remains in the background. If speakers adopt such a perspective, then they may pick lexical units belonging to domains that foreground the source of motion, such as slip, leave, detach (the Greek lexemes: apokolóme, ksekoláo, févgo, and $\gamma l i s t r a ́ o)$. Some of these units are exemplified in (18)-(20).

\section{(Frame 3; event type 1)}

$\begin{array}{llll}\text { Tis } & \text { ylístrise } & \text { to } & \text { ðaxtilið } i \\ \text { her.GEN.CL } & \text { slip.3sG.PST } & \text { DEF.NOM.SG.N } & \text { ring.NOM.SG.N }\end{array}$

'The ring slipped off her (i.e. off her finger)'

\section{(Frame 3; event type 3)}
$T u$
éfize
to
kapélo
him.GEN.CL leave.3SG.PST
DEF.NOM.SG.N hat.NOM.SG.N
'His hat fell off' (Lit. The hat left from him)

\section{(Frame 3; event type 18)}

\begin{tabular}{|c|c|}
\hline & $\begin{array}{l}\text { vrá } \chi o s \\
\text { rock.NOM.SG.M }\end{array}$ \\
\hline
\end{tabular}

'The rock was detached'

Fig. 3 zooms in the 'detachment' frame. It visualizes its micro-frames and shows the different situations in which each verb can be used.

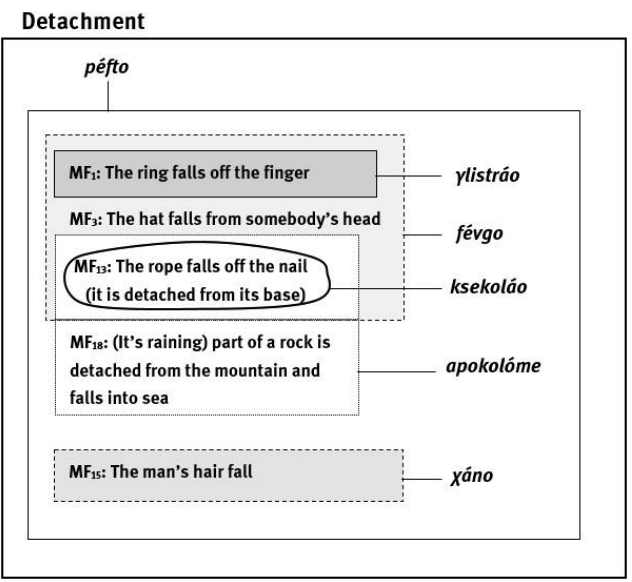

Figure 3. A micro-semantic map of the 'detachment' frame (FALLING domain in Greek) 


\subsection{The 'crashing down' frame}

The 'crashing down' frame allows the use of the dominant verb but other encoding strategies are also possible. When the crashing event involves the collapse of the ice layer or of the floor, kataréo 'collapse' is chosen (see (21)) and the use of the dominant strategy is ruled out.

\section{(Frame 4; event type 22)}

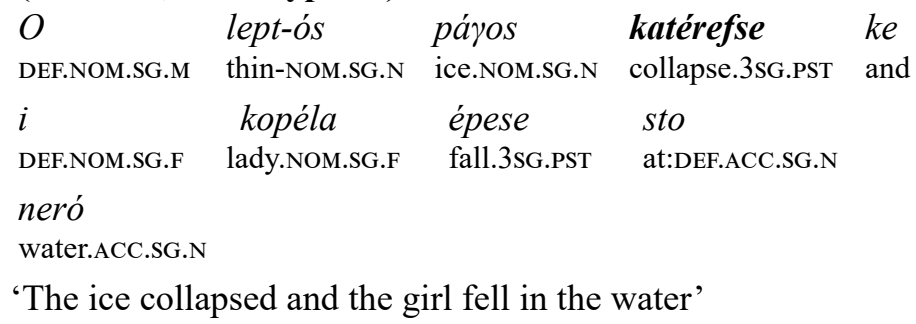

When the event involves a building (or other constructions such a bridge) falling into pieces (with the goal of motion usually being the ground), several verbs can be employed, namely gremizome 'fall down/ to pieces', kataréo 'collapse', and katakrimnizome 'crumble'. Consider (22)-(24).

\section{(Frame 4; event type 23)}

$\begin{array}{lll}\text { To } & \text { ktírio } & \text { gremístike } \\ \text { DEF.NOM.SG.N } & \text { building.NOM.SG.N } & \text { pull.down.3SG.PST.PASS } \\ \text { 'The building } & \text { was pulled down' }\end{array}$

(23) $T o$

\section{ktírio}

katérefse

DEF.NOM.SG.N building.NOM.SG.N collapse.3SG.PST

'The building collapsed'
To
ktírio
katakrimnístike
DEF.NOM.SG.N building.NOM.SG.N
crumble.3sG.PST.PASS
'The building was pulled down'

In event type 23, the cause of the event is an inanimate entity (a non-prototypical agent), namely the earthquake. In the condition of an inanimate cause, péfto, gremízome, kataréo, and katakrimnizome are accessible. Conversely, if a prototypical agent, e.g. a fireman, is considered to be the cause of the collapse, only gremizome is acceptable (cf. [Antonopoulou 1987: 182-183]). 


\section{Semasiological dimension: Polysemy of péfto in Greek}

The onomasiological analysis demonstrated the predominance of péfto within the FALLING domain. This section sets out to give an account of the semantics of this basic verb. Table 6 lists all the senses (as a paraphrase) found in the sample of CGT (as well as the labels used in the coding), along with their frequencies, and further divides the senses into literal and non-literal ones. ${ }^{10}$

Table 6. Frequency of lexical senses of péfto in CGT

\begin{tabular}{|l|l|c|l|}
\hline \multicolumn{1}{|c|}{ Paraphrase } & \multicolumn{1}{|c|}{ Label } & Literal & Frequency \\
\hline $\begin{array}{l}\text { 'vertical downward motion } \\
\text { (uncontrolled)' }\end{array}$ & vert.down.unctrl & yes & $95(16,93 \%)$ \\
\hline $\begin{array}{l}\text { 'to become lower in level, amount } \\
\text { or value' }\end{array}$ & lower & no & $87(15,5 \%)$ \\
\hline $\begin{array}{l}\text { 'sb is coincidentally faced with } \\
\text { a situation' } \\
\text { (e.g. to be obtained or to be caught } \\
\text { by someone [by chance]) }\end{array}$ & faced.with.situation & no & $50(8,91 \%)$ \\
\hline $\begin{array}{l}\text { 'lose of vertical orientation } \\
\text { (uncontrolled)' }\end{array}$ & lose.vert.unctrl & yes & $41(7,3 \%)$ \\
\hline $\begin{array}{l}\text { 'vertical downward motion } \\
\text { (metaphorical)' }\end{array}$ & vert.down.met & no & $41(7,3 \%)$ \\
\hline 'dash, fall violently on' & dash & yes & $39(6,95 \%)$ \\
\hline 'be affected' & be.affected & no & $29(5,16 \%)$ \\
\hline 'lose of vertical orientation (controlled)' & lose.vert.ctrl & yes & $21(3,74 \%)$ \\
\hline $\begin{array}{l}\text { 'to change into another state, condition } \\
\text { or mood' }\end{array}$ & enter.state & no & $19(3,38 \%)$ \\
\hline 'be killed' & killed & no & $18(3,20 \%)$ \\
\hline 'vertical downward motion (controlled)' & vert.down.ctrl & yes & $17(3 \%)$ \\
\hline $\begin{array}{l}\text { 'focus (emphasis falls on sth)/ devote } \\
\text { myself to doing sth' }\end{array}$ & focus & no & $12(2,13 \%)$ \\
\hline 'go to bed' & hang.down & $10(1,78 \%)$ \\
\hline 'hang down' & $8(1,42 \%)$ \\
\hline
\end{tabular}

${ }^{10}$ Examples of the senses that are not discussed in this Section are provided in the Appendix. 


\begin{tabular}{|l|l|c|c|}
\hline \multicolumn{1}{|c|}{ Paraphrase } & \multicolumn{1}{|c|}{ Label } & Literal & \multicolumn{1}{c|}{ Frequency } \\
\hline $\begin{array}{l}\text { 'go over/ onto a surface (extend/cover; } \\
\text { metaphorical)' }\end{array}$ & over.surface.met & no & $8(1,42 \%)$ \\
\hline 'commit' & commit & no & $7(1,24 \%)$ \\
\hline 'where or when is X' & where.when & no & $7(1,24 \%)$ \\
\hline 'is the responsibility of' & responsibility & no & $6(1 \%)$ \\
\hline ' crashing down' & crashing.down & yes & $6(1 \%)$ \\
\hline 'estimate' & estimate & no & $6(1 \%)$ \\
\hline 'repeated action' & repeat.action & yes & $6(1 \%)$ \\
\hline $\begin{array}{l}\text { 'go over/ onto a surface (extend/cover } \\
\text { partly or fully)' }\end{array}$ & over.surface & no & $6(1 \%)$ \\
\hline 'to lose a position of power & lose.power & no & $4(0.7 \%)$ \\
\hline or surrender' & detach.met & no & $4(0.7 \%)$ \\
\hline detachment' & detach & yes & $4(0.7 \%)$ \\
\hline 'fit' & Fit & no & $3(0.5 \%)$ \\
\hline 'dash, fall violently on (metaphorical)' & dash.met & no & $3(0.5 \%)$ \\
\hline 'crashing down on (metaphorical)' & crashing.down.met & no & $2(0.35 \%)$ \\
\hline 'tease' & tease & no & $1(0.17 \%)$ \\
\hline 'surprise (and catch)' & surprise & $1(0.17 \%)$ \\
\hline & $\begin{array}{l}\text { Total } \\
\text { 'dmetaphorical)' }\end{array}$ & $561(100 \%)$ \\
\hline
\end{tabular}

A first remark about Table 6 is that a high proportion of tokens of péfto is used non-literally. In fact, the non-literal uses prevail over the literal ones (Use non-lit: $322(57,4 \%)$ vs. Use $\left.\mathrm{lit}_{\text {lit }}: 239(42,6 \%)\right)$. It should be noted though that the total of 322 tokens used non-literally belongs to 20 different senses (i.e. one different sense per 16,1 tokens), whereas the total of 239 tokens used literally belongs to 10 senses (i.e. one different sense per 23,9 tokens).

The second observation is that the four frames discussed in Section 4 are all attested in the sample:

(a) Frame 1: Paraphrase 1 ('vert.down.unctrl'; ex. 1b)

(b) Frame 2: Paraphrase 4 ('lose.vert.unctrl'; ex. 2b)

(c) Frame 3: Paraphrase 25 ('detach' ex. 3b)

(d) Frame 4: Paraphrase 19 ('crashing.down'; ex. 4b) 
Interestingly, the sense corresponding to frame 1, i.e. that of 'vert. down.unctrl', is the most frequent one in the corpus $(N=95)$. This is also the sense with the highest number of different ID tags, i.e. ID tags with non-zero values $(N=39$; cf. the number of different ID tags of 'lower', i.e. of the second most frequent sense: $N=33$ ), which evidences its unmarked status (cf. [Gries, Divjak 2009: 64]). Thus, from the point of view of frequency and markedness, 'vert.down.unctrl' is the prototypical sense (on the relation between frequency of occurrence and prototypicality, see [Gilquin 2008]; [Arppe et al. 2010]; [Schmid 2010]; [Jansegers et al. 2015]; among others). It should be noted that frequency and markedness are not the only indicators for prototype identification. Establishing the prototype of a linguistic item is a rather complex process, which often requires the identification of the historically earliest attested sense or the order of acquisition of the various senses by children (see [Tyler, Evans 2003]; [Gries 2006]; [Arppe et al. 2010]; among many others). However, these various ways of approaching prototypicality fall beyond the scope of the current study.

The full annotation scheme presented in Table 3 revealed additional interesting patterns as far as the verb's collocation patterns is concerned. Specifically, péfto in all senses that involve a (non-abstract) TR's motion towards a LM (irrespective of the orientation, which can be either vertical or horizontal) favors the explicit expression of the goal of motion. Table 7 shows the distribution of the PPs accompanying péfto in the sample. Goal PPs prevail over source PPs $\left(N_{\text {goal }}=115 v s\right.$. $\left.N_{\text {source }}=20\right)$. Given that both the source and the goal should be considered core frame elements of péfto,,$^{11}$ this imbalance in frequency between the two might seem unjustifiable. It fits, however, particularly well with what has been claimed about the predominance of goals in the encoding of motion events, a phenomenon which has been referred to as 'source-goal asymmetry'. ${ }^{12}$ Specifically in discourse, it has been shown that motion verbs display preferences for

$11 \mathrm{cf}$. the annotation of the English fall in FrameNet; https://framenet2.icsi.berkeley. edu/fnReports/data/lu/lu6257.xml?mode=annotation

12 The phenomenon has also been termed 'goal bias', 'goal-over-source bias/ principle', and 'goal-over-source-predominance'. For an early formulation of the hypothesis, see Ikegami, 1987; for motivating factors for this asymmetry, see [Dirven, Verspoor 2004], [Stefanowitsch, Rohde 2004, Regier, Zheng 2007]; for an overview, see [Papafragou 2010: 1064-1066]; for a recent large-scale corpus-based study of motion verbs in English, see [Stefanowitsch 2018]. 
goal paths (see [Stefanowitsch, Rohde 2004]; [Ishibashi 2010]; [Georgakopoulos 2018]).

Table 7. Frequencies of the PPs co-occurring with péfto in the sample of the CGT corpus

\begin{tabular}{|l|r|c|c|c|}
\hline \multicolumn{1}{|c|}{ Sense } & Goal & Source & Source \& Goal & Other \\
\hline crashing.down & 4 & & & \\
\hline dash & 37 & & & \\
\hline detach & & 1 & & \\
\hline go.bed & 4 & & & 4 \\
\hline lose.vert.ctrl & 9 & & & 1 \\
\hline lose.vert.unctrl & 10 & & & 1 \\
\hline vert.down.unctrl & 42 & 15 & & 6 \\
\hline vert.down.ctrl & 9 & 4 & & \\
\hline Total & 115 & 20 & & \\
\hline
\end{tabular}

Beyond the distribution of goal and source elements, the full annotation scheme allows us to explore in more detail further aspects of the semantics of péfto. Specifically, through multivariate exploratory statistical methods (in particular, hierarchical agglomerative cluster analysis), it is possible to represent (dis)similarities between senses in the form of a dendrogram. In order to obtain a more coherent picture, only those senses that were attested more than 10 times in the sample, namely 12 items, were submitted to a hierarchical cluster analysis (see [Berez, Gries 2009] and [Glynn 2014] for a similar methodological decision to exclude rare senses). ${ }^{13}$ The resulting cluster dendrogram, which is based on all features included in the annotation scheme (18 ID tags across 450 sentence data), can be seen in Fig. 4. It is clustered with the Ward clustering method and shows how the different senses are grouped together. Note that these results should be approached with caution due to the limited corpus size. However, some interesting preliminary observations can be made.

In Fig. 4, we see two main branches. The first branch contains the senses 'vert.down.met', 'enter.state', 'focus', 'faced.with.situation', and 'lower', whereas the second branch comprises the senses 'go.bed', 'lose.vert.unctrl',

${ }^{13}$ All the citations of the sense 'be affected' described a situation in which somebody falls victim to something (e.g., to the flu, to a scam) and appeared in the formulaic construction ' $\mathrm{X}$ falls victim to $\mathrm{Y}$ '. This sense was therefore also excluded from further investigation. 


\section{Cluster dendrogram with p-values (\%)}

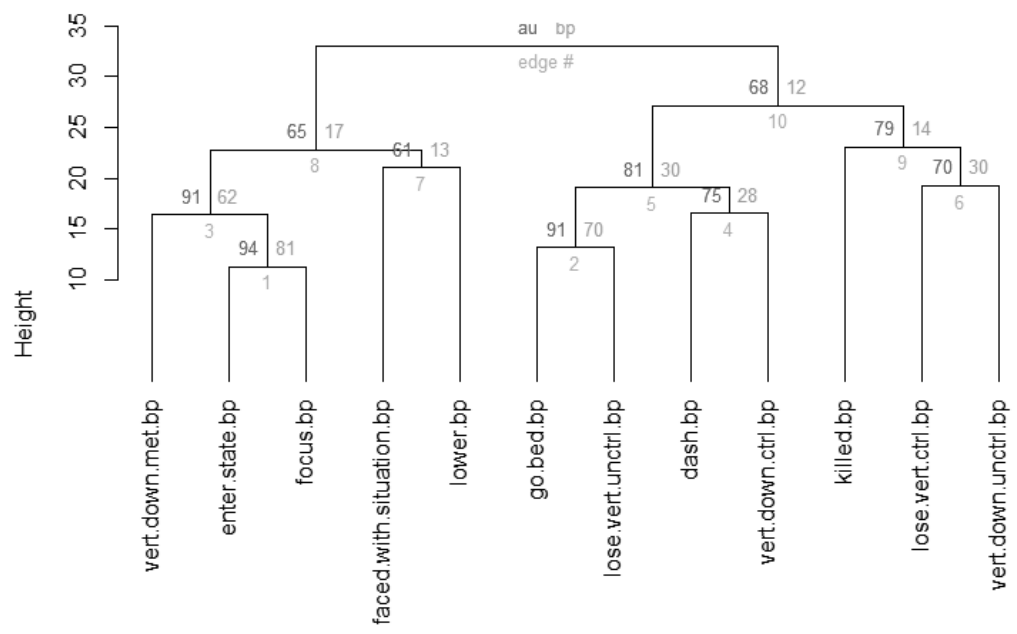

Distance: canberra

Cluster method: ward.D2

Figure 4. Hierarchical cluster analysis of 12 lexical senses of péfto in CGT Distance metric: Canberra; amalgamation rule: 'Ward'

'dash', 'vert.down.ctrl', 'killed', 'lose.vert.ctrl', and 'vert.down.unctrl'. This means that the analysis has grouped together most figurative senses (in fact, the left branch shows a clear structure as a whole, as evidenced by the fact that it contains only figurative senses) and all cases of literal motion (right branch). The senses that show the maximum distance and that are in turn merged higher on the tree are the senses 'lose.vert.ctrl' and 'enter.state' '(max(pefto.dist): 26.76), an intuitively logical result. The minimum distance between the items is observed between 'enter.state' and 'focus' (min(pefto. dist): 11.50 (distances were computed with the function $\operatorname{dist}()$ in $\mathrm{R})$. These senses are merged lower on the tree. ${ }^{14}$ Their grouping is intuitively reasonable, since both seem to emerge from the spatial scheme of downward vertical movement. They presuppose going into some abstract substance and remaining there (i.e. both place particular importance on the goal). This grouping can be further explained with reference to their distributional

${ }^{14}$ Note that this grouping reaches statistical significance as shown by its AU (Approximately Unbiased) $p$-value ( $94 \%$; alpha set at .10). The figures in green show the BP (bootstrap probability) value, which is less accurate than the AU value. 
similarity. In order to identify those features that are distinctive of this cluster, I explored the absolute differences between the proportions of each value of every variable (cf. [Levshina 2015: 313-315]). Specifically, I computed the differences between the average values of the <enter.state, focus $>$ cluster and all other senses and then sorted them. This process demonstrated that the $<$ enter.state, focus $>$ cluster has a much higher proportion of abstract LMs than the other senses (average diff. $=93 \%$ ). ${ }^{15}$ Further, it indicated that the factor USE is the second most important factor discriminating between $<$ enter.state, focus $>$ and the other senses (in the ID tag level USE.FIGURATIVE: average diff. $=61 \%$ ). The third distinctive feature is LM_NUM.singular (average diff. $=21 \%$ ), and the fourth their co-occurrence with an adverbial (average diff. $=19 \%$ ). All these features are present in examples (26) and (27).

\section{Sense 12 'focus'}

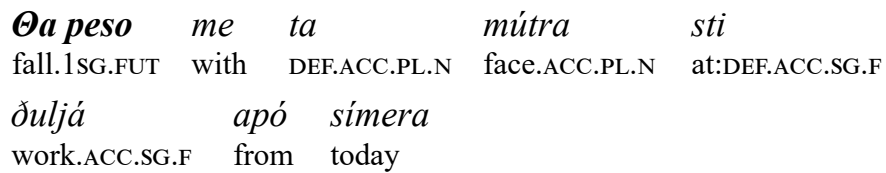

'Starting from today, I will binge on work' [CGT: WFBG08-5003]

\section{Sense 9 'enter.state'}

$\begin{array}{llll}\begin{array}{l}\text { Apó tóte } o \\ \text { from then DEF.NOM.SG.M }\end{array} & \text { Nikolós } & \begin{array}{l}\text { épese } \\ \text { Nicolos.NOM.SG.M }\end{array} & \text { fall.3sg.PST } \\ \text { disménia ... } & & & \\ \text { disfavor.ACC.SG.F } & & & \end{array}$

'Since then Nicolos has fallen into disfavor...' [GCT: WFBG08-5007]

In (26), an entity who is engaged in a process accords special importance to an event or state of affairs that has an impact on the success of the process. In (27), an entity ends up in a final situation, which it was not in before (cf. the frame [Transition_to_a_state] in FrameNet; https://framenet2. icsi.berkeley.edu). This example constitutes a linguistic realization of the metaphorical mappings CHANGE OF STATE IS A CHANGE OF A LOCATION and CHANGE IS MOTION (cf. [Radden 1996]).

The sense 'vert.down.met', which clusters with 'enter.state' and 'focus', involves an abstract TR undergoing an abstract motion which ends

15 This percentage is the average difference within the ID tag LM_TYPE between the cluster <enter.state, focus> (Group 1) and the group comprising all other senses (Group 2). Within this ID tag, all entities (100\%) in Group 1 are abstract, whereas only $7 \%$ of all entities in Group 2 are abstract. Hence the $93 \%$ difference. 
up in a - typically - unpleasant situation that is difficult to escape from (e.g., an ambush, a vacuum; see (28)). As such, it is conceptually similar to 'enter.state'.

Sense 5 'vert.down.met'

\begin{tabular}{|c|c|c|c|}
\hline 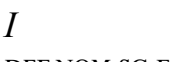 & prospátia & épese & sto \\
\hline $\begin{array}{l}\text { DEF.NOM.SG.F } \\
\text { kenó }\end{array}$ & effort.NOM.SG.F & fall.3SG.PST & at:DEF.ACC.SG.M \\
\hline
\end{tabular}

vacuum.ACC.SG.N

'The effort fell into the vacuum'[CGT: WACG13-0028]

The second sub-cluster of the first branch merges 'lower' and 'faced_with situation'. These two senses are exemplified in (29) and (30), respectively.

\section{Sense 2 'lower'}

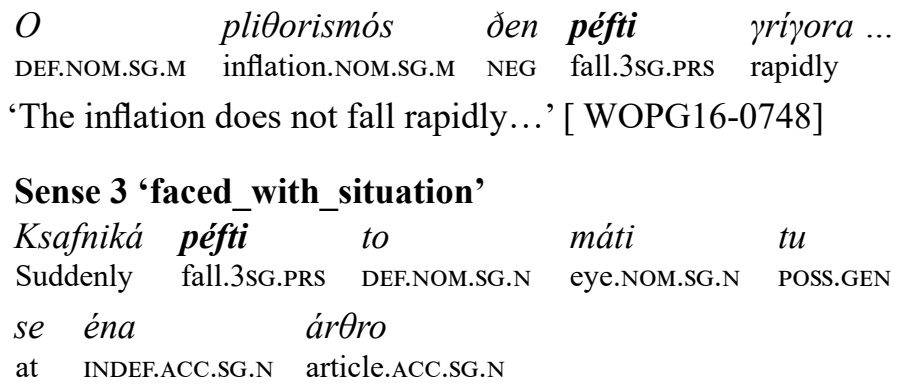

'Suddenly, his eye fell on one article' [CGT: WFCG33-5001]

Example (29) describes the change of an item's position on a scale (cf. the frame [Change_position_on_a_scale] in FrameNet; https://framenet2.icsi.berkeley.edu). The initial as well as the final value of the item can be explicitly expressed, but this is not necessarily the case as (29) shows. Example (30) in turn involves a process in which an entity is being found/ discovered/ recovered. The three most distinctive ID tag levels for this sub-cluster are: the USE.FIGURATIVE (average diff. $=61 \%$ ), the TR.INANIMATE (average diff. $=55 \%$ ) and the LM_TYPE.REPRESENTATION (average diff. $=30 \%$ ). It should be added here that the factor ranked third, namely the feature LM_TYPE.REPRESENTATION, is not found in the behavioral profile of 'faced_with_situation', but only in that of 'lower'. Crucially, this feature, which includes LMs that express the position on the scale where an item (e.g. a share) ends up, follows from the frame the sense 'lower' evokes, i.e. [Change_position_on_a_scale].

As has already been mentioned, the branch on the right of Fig. 4 shows also some structure, since it consists mainly of cases of literal motion. 
More specifically, the first sub-branch on the right edge of Fig. 4 contains the senses 'lose.vert.ctrl' and 'vert.down.unctrl'. The former involves a TR changing its initial vertical orientation while falling. In the relevant examples, the movement from point A to point B takes place on the same surface, see (31)-(32). The latter sense describes an entity falling from an elevated surface, see (33). The most distinctive ID tag level for this sub-cluster is the USE.LITERAL one (average diff. $=58 \%$ ), followed by the properties LM_TYPE.concrete (average diff. $=32 \%$ ) and CLAUSE. main (average diff. $=19 \%$ ).

Sense 8 'lose.vert.ctrl'

$\begin{array}{llll}\text { I } & \text { mána } & \begin{array}{l}\text { épese } \\ \text { fall.3sG.PST }\end{array} & \text { sta } \\ \text { DEF.NOM.SG.F } & \text { mother.NOM.SG.ACC.PL.N } \\ \text { yónata } & & & \\ \text { knee.ACC.PL.N } & & & \end{array}$

'The mother fell on knees' [GCT: WFBG08-5011]

$\begin{array}{lllll}\text { Emis } & \text { pésame } & \text { sto } & \text { xjóni } & \text { akinit-i } \\ \text { we } & \text { fall.1PL.PST } & \text { at:DEF.ACC.SG.N } & \text { snow.ACC.SG.N } & \text { still-NOM.PL }\end{array}$

'We fell to the snow and we stood still' [GCT: WFBG10-0001]

Sense 1 'vert.down.unctrl'

$\begin{array}{lllll}\text { Péftane } & t a & \text { fila } & \text { apó } & \text { ta } \\ \text { fall.3PL.PST } & \text { DEF.NOM.PL.N } & \text { leave.NOM.PL.N } & \text { from } & \text { DEF.ACC.PL.N } \\ \text { ðédra } & & & & \end{array}$

tree.ACC.PL.N

'The leaves were falling from the trees' [GCT: WFBG08-0001]

Given that the analysis has merged two senses in which the moving entity either has control over the motion ('lose.vert.ctrl') or has no control over it ('vert.down.unctrl'), it stands to reason that the parameter of cause (see Section 3.1) is not a crucial factor in grouping the senses together. This is also clear in the sub-branch < go.bed, lose.vert.unctrl>, which comprises a sense involving a self-moving Trajector who has control of their action and whose motion is intentional (see (34)) as well as a sense in which the motion is without control (see (35)).

\section{Sense 13 'go.bed'}

$\begin{array}{llllll}\text { Apópse } & \theta a & \text { protimúsa } & \text { na } & \text { péso } & \text { noris } \\ \text { Tonight } & \text { FUT } & \text { prefer.1SG.PST } & \text { MODAL } & \text { fall.1SG.NON PST } & \text { early }\end{array}$

'I would prefer to go to bed early tonight' [GCT: WFBG08-0003] 


\section{Sense 4 'lose.vert.unctrl'}

\begin{tabular}{|c|c|c|c|}
\hline $\begin{aligned} \text {... éxase } \\
\\
\text { lose.3sG.PST }\end{aligned}$ & $\begin{array}{l}\text { tin } \\
\text { DEF.ACC.SG.F }\end{array}$ & $\begin{array}{l}\text { isoropía } \\
\text { balance.ACC.SG.F }\end{array}$ & $\begin{array}{l}t u \\
\text { his.GEN }\end{array}$ \\
\hline $\begin{array}{l}\text { épese } \\
\text { fall.3sG.PST }\end{array}$ & & & \\
\hline
\end{tabular}

'He lost his balance and fell down'[GCT: WFBG09-5007]

The most distinctive ID tag level of this sub-branch is again the USE.LITERAL one (average diff. $=50 \%$ ), followed by the features TR.animate (average diff. $=32 \%$ ), LM_TYPE.concrete (average diff. $=32 \%$ ) and the absence of an adverbial (average diff. $=32 \%$ ). The comparison between the subbranch $<$ go.bed, lose.vert.unctrl $>$ and the $<$ dash, vert.down.ctrl $>$ one reveals that the most important feature explaining their difference is the presence vs. absence of an adverbial (average diff. $=41 \%$ ). Specifically, in the latter group $88,5 \%$ of the citations explicitly express an adverbial (see (36) in which the TR runs towards an animate LM very quickly and (37) which describes a scene in which paratroopers jumped out of an airplane and landed on a mountain), whereas in the former an adverbial is found in $48 \%$ of the tokens (see, e.g., (34)).

\section{Sense 6 'dash'}

$\begin{array}{lllll}\text { Xarúmen-os } & \text { péfti } & \text { páno } & \text { stin } & \text { Evantúla } \\ \text { happy-NOM.SG.M } & \text { fall.3SG.PRS } & \text { on } & \text { at:DEF.ACC.SG.F } & \text { Evanthula.ACC.SG.F }\end{array}$

'He was happy and he fell on Evanthula' [GCT: WFBG08-5006]

\section{Sense 11 'vert.down.ctrl'}

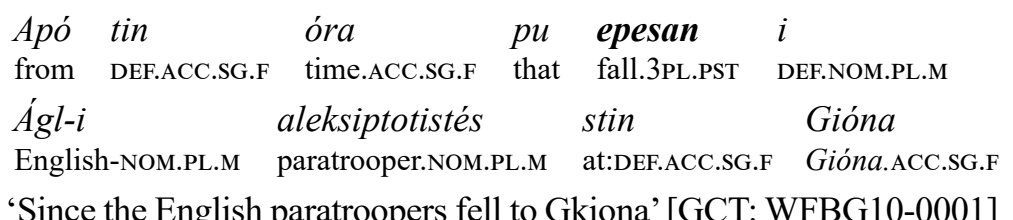

\section{Conclusions}

Building on the insights of the frame-based methodology for lexical typology and through an additional corpus-based behavioral profile analysis, this study has examined various aspects of the semantics of the FALLING domain in Greek. The main points made above can be summarized as follows. 
First, the onomasiological analysis has shown that the Greek system should be classified as dominant, since the same lexeme, i.e. péfto, can be used in all frames and in a wide range of situation types within these frames. Its use is ruled out only in a few cases one of which involves the motion of a substance out of a container under the effect of gravity, in which cases the construction 'A xinete se $C$ ' is used. We observed that the lexical opposition between the two antagonistic verbs as a result of the parameter of fluidity poses a problem when it comes to the representation of the boundaries of the lexemes in semantic space. A representation that visualizes micro-frames (and not only frames) as nodes provides a possible solution to this problem. Additionally, the Greek FALLING system, albeit dominant, gives space to other encoding strategies to emerge. As a matter of fact, 13 additional motion verbs can be used to describe the various situation types. However, these verbs are confined within the boundaries of each frame. This is illustrated in Fig. 5, which is a geometrical representation of the microframes in the FALLING domain in Greek.

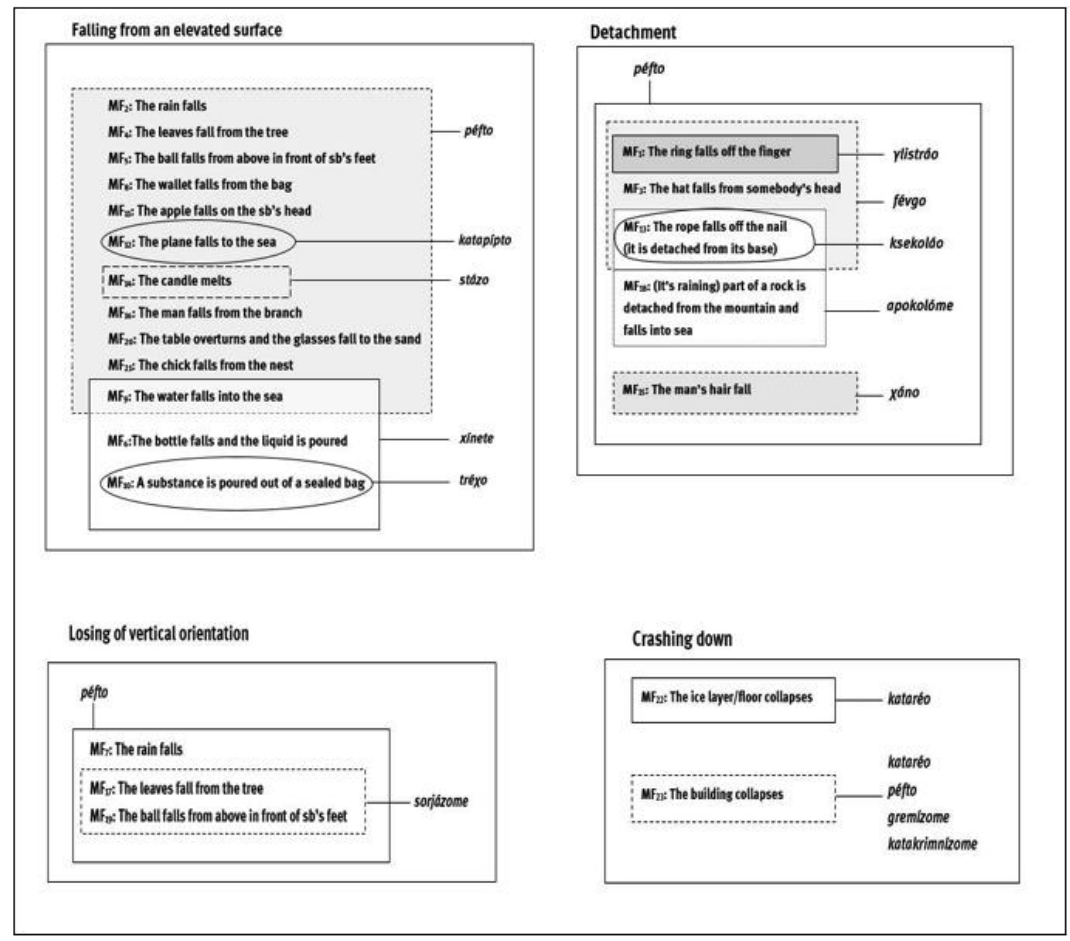

Figure 5. A micro-semantic map of the FALLING domain in Greek 
Second, the semasiological analysis has provided an account of the semantics of péfto. Specifically, it offers corpus-based evidence concerning the prototypical sense of the lexeme. According to the criteria of frequency and markedness, it turns out that the prototypical sense of péfto refers to the motion of a TR from a higher to a lower level. Besides the establishment of the prototype identification, the semasiological analysis has also assisted the identification of some preferred patterns of this lexeme. In particular, it reveals that péfto in all senses that involve a TR's motion towards a LM favors the explicit expression of the goal of motion. Finally, through a cluster analytic approach, it was possible to represent (dis)similarities between senses in the form of a dendrogram. Although the classification of senses based on dictionaries might be considered a subjective process, the annotation of distributional and semantic ID tags enabled us to group senses in a less subjective way. Finally, in some cases, the specific morpho-syntactic and semantic properties that were found to correlate with the various senses of péfto appear to follow from the frames (in the Fillmorean sense) these senses evoke.

Future research could take into account discourse-pragmatic information and explore the possibility that some discourse-pragmatic features are particular relevant for particular senses of péfto. Such an approach will expand the scope of corpus-based analyses by representing senses as enriched lexical constructions, which are not being exclusively fed with morpho-syntactic and semantic features (see [Georgakopoulos et al. 2020]). In addition, the full list of senses that appear in Table 6 may be considered (see also the Appendix). In doing so, further questions related to polysemy could be addressed, e.g. "how can one determine whether two meanings are clearly different or merely shades of meaning" [Jansegers et al. 2015: 390]. Finally, a semasiological analysis of the whole set of verbs belonging to the FALLING domain will determine the range of senses associated with each verb and will unravel shared patterns of polysemy. This will conclude the cycle of analysis, which takes the sense-to-form approach as a point of departure, then proceeds adopting a form-to-sense approach, and in a final step returns to the sense-to-form approach.

\section{Abbreviations}

ACC - accusative; CL — clitic; DEF — definite article; INDEF — indefinite article; F — feminine; FUT - future; GEN - genitive; LM - landmark; M — masculine; MODAL — modality; N — neutral; NOM — nominative; NON_PST — non past; PASS — passive; PL — plural; POSS — possessive ; PRS — present; PST — past; SG — singular; TR — trajectory. 


\section{References}

Anderson 1982 - L. B. Anderson. The 'perfect' as a universal and as a language-particular category. P. J. Hopper (ed.). Tense-aspect: Between semantics \& pragmatics. Amsterdam; Philadelphia: John Benjamins, 1982.

Antonopoulou 1987 - E. Antonopoulou. Prototype Theory and the Meaning of Verbs, with Special Reference to Modern Greek Verbs of Motion. PhD Thesis. SOAS, University of London, 1987. P. 227-264.

Apresjan 2000 - J. D. Apresjan. Systematic Lexicography. Oxford: Oxford University Press, 2000.

Arppe et al. 2010 - A. Arppe, G. Gilquin, D. Glynn, M. Hilpert, A. Zeschel. Cognitive corpus linguistics: Five points of debate on current theory and methodology. Corpora. 2010. Vol. 5. Iss. 1. P. 1-27.

Atkins 1987 - B. T. S. Atkins. Semantic ID tags: Corpus evidence for dictionary senses. Proceedings of the Third Annual Conference of the UW Centre for the New Oxford English Dictionary. Waterloo, Canada, 1987. P. 17-36.

Bassea-Bezantakou 1992 - C. Bassea-Bezantakou. Simasiologikes Theories tor Rimaton Kiniseos tis Neas Ellinikis Glossas [A Semantic Analysis of Motion Verbs in Modern Greek]. Kardamitsa: Athens, 1992.

Berez, Gries 2009 - A. L. Berez, S. T. Gries. In defense of corpus-based methods: A behavioral profile analysis of polysemous get in English. S. Moran, D. S. Tanner, M. Scanlon (eds.). Proceedings of the $24^{\text {th }}$ Northwest Linguistics Conference. University of Washington Working Papers in Linguistics. Vol. 27. Seattle, WA: Department of Linguistics, 2009. P. 157-166.

Divjak, Gries 2006 — D. Divjak, S. T. Gries. Ways of trying in Russian: Clustering behavioral profiles. Corpus Linguistics and Linguistic Theory. 2006. Vol. 2. Iss. 1. P. 23-60. DOI 10.1515/CLLT.2006.002

Divjak, Fieller 2014 - D. Divjak, N. Fieller. Cluster analysis: Finding structure in linguistic data. D. Glynn, A. J. Robinson (eds.). Corpus Methods for Semantics. Quantitative studies in polysemy and synonymy. Amsterdam: John Benjamins, 2014. P. 405-441.

Divjak 2010 - D. Divjak. Structuring the Lexicon: A Clustered Model for Near-Synonymy. Berlin: de Gruyter, 2010.

Dirven, Verspoor 2004 - R. Dirven, M. Verspoor. Cognitive explorations of language and linguistics. Amsterdam; Philadelphia: John Benjamins, 2004.

Firth 1957 - J. R. Firth. Papers in Linguistics. London: Oxford University Press, 1957.

Geeraerts 2010 - D. Geeraerts. Theories of Lexical Semantics. Oxford, New York: Oxford University Press, 2010.

Georgakopoulos 2018 - T. Georgakopoulos. A frame-based approach to the sourcegoal asymmetry: Synchronic and diachronic evidence from Ancient Greek. Constructions and Frames. 2018. Vol. 10. No. 1. P. 61-97.

Georgakopoulos, Polis 2018 - T. Georgakopoulos, S. Polis. The semantic map model: State of the art and future avenues for linguistic research. Language and Linguistics Compass. 2018. Vol. 12. Iss. 2. P. 1-33. DOI: E12270 LNCO-0727.R1. 
Georgakopoulos 2019 — T. Georgakopoulos. Semantic Maps. M. Aronoff (ed.). Oxford Bibliographies in Linguistics. New York: Oxford University Press, 2019. DOI: 10.1093/OBO/9780199772810-0229

Georgakopoulos et al. 2020 - T. Georgakopoulos, S.-E. Lincke, K. Nikiforidou, A. Piata. On the polysemy of motion verbs in Ancient Greek and Coptic: Why lexical constructions are important. Studies in Language. 2020. Vol. 44. No. 1. P. 27-69.

Gilquin 2008 - G. Gilquin. What you think ain't what you get: Highly polysemous verbs in mind and language. J. R. Lapaire, G. Desagulier, J.-B. Guignard (eds.). Du fait grammatical au fait cognitif. From gram to mind: Grammar as cognition. Pessac: Presses Universitaires de Bordeaux, 2008. P. 235-255.

Glynn 2014 - D. Glynn. The many uses of run: Corpus methods and Socio-Cognitive Semantics. D. Glynn, A. J. Robinson (eds.). Corpus Methods for Semantics: Quantitative studies in polysemy and synonymy. Amsterdam: John Benjamins, 2014. P. 117-144

Goutsos 2010 - D. Goutsos. The Corpus of Greek Texts: A Reference Corpus for Modern Greek. Corpora. 2010. Vol. 5. No. 1. P. 29-44.

Gries 2006 - S. T. Gries, Corpus-based methods and cognitive semantics: The many senses of to run. S. T. Gries, A. Stefanowitsch (eds.). Corpora in Cognitive Linguistics. Berlin; New York: Mouton De Gruyter, 2006. P. 57-99.

Gries, Divjak 2009 - S. T. Gries, D. Divjak. Behavioral profiles: A corpus-based approach to cognitive semantic analysis. V. Evans, S. Pourcel (eds.). New directions in cognitive linguistics. Amsterdam: John Benjamins, 2009. P. 57-75.

Gries 2010 - S. T. Gries. Behavioral profiles: A fine-grained and quantitative approach in corpus-based lexical semantics. The Mental Lexicon. 2010. Vol. 5. Iss. 3. P. 323346. DOI: 10.1075/ml.5.3.04gri.

Hanks 1996 - P. Hanks. Contextual dependency and lexical sets. International Journal of Corpus Linguistics. 1996. Vol. 1. No. 1. P. 75-98.

Haspelmath 2003 - M. Haspelmath. The geometry of grammatical meaning: Semantic maps and cross-linguistic comparison. M. Tomasello (ed.). The new psychology of language. Vol. 2. New York: Erlbaum, 2003. P. 211-243.

Haspelmath 2010 - M. Haspelmath. Comparative concepts and descriptive categories in crosslinguistic studies. Language. 2010. Vol. 6. No 3. P. 663-687.

Haspelmath 2018 - M. Haspelmath. How comparative concepts and descriptive linguistic categories are different. D. Van Olmen, T. Mortelmans, F. Brisard (eds.). Aspects of linguistic variation. Berlin: De Gruyter, 2018. P. 83-113.

Holton et al. 2012 - D. Holton, P. Mackridge, I. Philippaki-Warburton, V. Spyropoulos. Greek: A Comprehensive Grammar. Second Edition. London: Routledge, 2012.

Janda, Lyashevskaya 2011 - L. A. Janda, O. Lyashevskaya. Aspectual Pairs in the Russian National Corpus. Scando-Slavica. 2011. Vol. 57. Iss. 2. P. 201-215.

Jansegers et al. 2015 - M. Jansegers, C. Vanderschueren, R. Enghels. The polysemy of the Spanish verb sentir: A behavioral profile analysis. Cognitive Linguistics. Vol. 26. Iss. 3. P. 381-421. DOI: 10.1515/cog-2014-0055.

Ikegami 1987 — Y. Ikegami, 'Source' vs. 'goal': A case of linguistic dissymmetry. R. Dirven, G. Radden (eds.). Concepts of case. Tübingen: Narr, 1987. P. 122-146. 
Ishibashi 2010 - M. Ishibashi. The (a)symmetry of source and goal in motion events in Japanese: Evidence from narrative data. G. Marotta, A. Lenci, L. Meini, F. Rovai (eds.). Space in language: Proceedings of the Pisa International Conference. Pisa: Edizioni ETS, 2010. P. 514-531.

Langacker 2008 - R. W. Langacker. Cognitive Grammar: A basic Introduction. Oxford: Oxford University Press.

Levshina 2015 - N. Levshina. How to do Linguistics with R: Data exploration and statistical analysis. Amsterdam; Philadelphia: John Benjamins, 2015.

List et al. 2018 - J.-M. List, M. Cysouw, S. Greenhill, R. Forkel (eds.). Concepticon. Jena: Max Planck Institute for the Science of Human History, 2018. Available at: http://concepticon.clld.org (accessed on 10.08.2020)

Maisak, Rakhilina 2007 - T. Maisak, E. Rakhilina (eds.). Glagoly dvizheniya v vode: Leksicheskaya tipologiya [Verbs of aqua-motion: Lexical typology]. Moscow: Indrik, 2007.

Papafragou 2010 - A. Papafragou. Source-Goal asymmetries in motion representation: Implications for language production and comprehension. Cognitive Science. 2010. Vol. 34. Iss. 6. 34. P. 1064-1092.

R Core Team 2015 - R Core Team. R: A language and environment for statistical computing. R Foundation for Statistical Computing, Vienna, Austria, 1999. Available at: http: www.R-project.org/ (accessed on 10.08.2020)

Radden 1996 - G. Radden. Motion metaphorized: The case of 'coming' and 'going'. E. Casad (ed.). Cognitive Linguistics in the redwoods: The expansion of a new paradigm in linguistics .Berlin: de Gruyter, 1996. P. 423-458.

Rakhilina, Reznikova 2014 - E. Rakhilina, T. Reznikova. Doing lexical typology with frames and semantic maps. National Research University Higher School of Economics. Working papers by the Basic Research Program: "Linguistics". 2014. No. 18. Available at: https://ssrn.com/abstract=2564011 (accessed on 10.08.2020)

Rakhilina, Reznikova 2016 - E. Rakhilina, T. Reznikova. A frame-based methodology for lexical typology. P. Juvonen, M. Koptjevskaja-Tamm (eds.). The lexical typology of semantic shifts. Berlin: de Gruyter, 2016. P. 95-129.

Regier, Zheng 2007 - T. Regier, M. Zheng. Attention to endpoints: A cross-linguistic constraint on spatial meaning. Cognitive Science. 2007. Vol. 31. Iss. 4. P. 705-719.

Reznikova, Vyrenkova 2015 - T. I. Reznikova, A. S. Vyrenkova. Semantics of falling: a cross-linguistic approach. National Research University Higher School of Economics. Working papers by the Basic Research Program: "Linguistics". 2015. No. 40. Available at: https://wp.hse.ru/data/2015/12/29/1136293661/40LNG2015. pdf (accessed on 10.08.2020)

Robinson 2014 - A. J. Robinson. Quantifying polysemy in Cognitive Sociolinguistics. D. Glynn, A. J. Robinson (eds.). Corpus Methods for Semantics: Quantitative studies in polysemy and synonymy. Amsterdam: John Benjamins, 2014. P. 87-115.

Schmid 2010 - H.-J. Schmid. Does frequency in text instantiate entrenchment in the cognitive system? D. Glynn, K. Fischer (eds.). Quantitative Methods in Cognitive Semantics: Corpus-Driven Approaches. Berlin; New York: de Gruyter, 2010. P. 101-133. 
Stefanowitsch, Rohde 2004 - A. Stefanowitsch, A. Rohde. The goal bias in the encoding of motion events. G. Radden, K.-U. Panther (eds.). Studies in linguistic motivation. Berlin: de Gruyter, 2004. P. 249-268.

Stefanowitsch 2018 - A. Stefanowitsch. The goal bias revisited: A collostructional approach. Yearbook of the German Cognitive Linguistics Association. 2018. Vol. 6. Iss. 1. P. 143-166.

Tyler, Evans - A. Tyler, V. Evans. The Semantics of English Prepositions. Spatial Scenes, Embodied Meaning and Cognition. Cambridge: Cambridge University Press, 2003.

\section{Sources}

Babiniotis 2002 - G. Babiniotis. Dictionary of Modern Greek. Athens: Lexicology Centre, 2002.

IMT (Idryma Manoli Triantafyllidi) 1998. Lexico tis Koinis Neoellinikis. Thessaloniki: Aristoteleio Panepistimio Thessalonikis. Institouto Neoellinikon Spoudon [Modern Greek Dictionary. Aristotle University of Thessaloniki. Institute of Modern Greek Studies (M. Triantafyllidis Foundation)], 1998.

\section{Appendix}

Lexical senses of péfto in CGT: additional examples.

\begin{tabular}{|c|c|c|}
\hline Paraphrase & Example (made-up) & Translation \\
\hline 'be affected' & Épese Oíma listías & $\begin{array}{l}\text { They robbed him (Lit. } \\
\text { He fell victim to robbery) }\end{array}$ \\
\hline 'killed' & Épese nekrós & He fell dead \\
\hline 'hang down' & $\begin{array}{l}\text { Ta maljá tis épeftan páno } \\
\text { stus ómus tis }\end{array}$ & $\begin{array}{l}\text { Her hair fell over her } \\
\text { shoulders }\end{array}$ \\
\hline $\begin{array}{l}\text { 'go over/ onto a surface } \\
\text { (extend/cover; } \\
\text { metaphorical)' }{ }^{16}\end{array}$ & 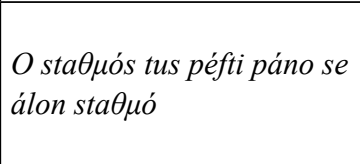 & $\begin{array}{l}\text { Their broadcasting } \\
\text { station falls on another } \\
\text { broadcasting station (i.e., } \\
\text { it covers its signal). }\end{array}$ \\
\hline 'commit & $\begin{array}{l}\text { Tríti forá pu épese se } \\
\text { paráptoma }\end{array}$ & $\begin{array}{l}\text { That was the third time he } \\
\text { committed a crime }\end{array}$ \\
\hline
\end{tabular}

${ }^{16}$ Other collocates in subject position: siopi 'silence', payomára 'chilliness', murmúrisma 'murmur'. 


\begin{tabular}{|c|c|c|}
\hline Paraphrase & Example (made-up) & Translation \\
\hline 'where or when is $\mathrm{X}$ ' & 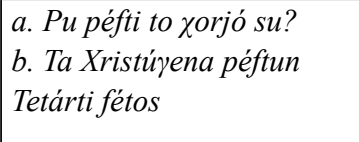 & $\begin{array}{l}\text { a. Where is your village? } \\
\text { b. This year Christmas } \\
\text { falls on Wednesday }\end{array}$ \\
\hline 'is the responsibility of' & I effini péfti stin kivérnisi & $\begin{array}{l}\text { The responsibility falls } \\
\text { onto the government }\end{array}$ \\
\hline 'crashing down' & I yéfira épese & The bridge collapsed \\
\hline 'estimate' & $\begin{array}{l}\text { Épese mesa stin próvlepsi } \\
\text { aftí ti forá }\end{array}$ & $\begin{array}{l}\text { He predicted correctly this } \\
\text { time }\end{array}$ \\
\hline 'repeated action' & Épeftan sféres vroxi & $\begin{array}{l}\text { Bullets were thrown like } \\
\text { rain }\end{array}$ \\
\hline $\begin{array}{l}\text { 'go over/ onto a surface' } \\
\text { (extend/cover partly } \\
\text { or fully) }\end{array}$ & $\begin{array}{l}\text { To fos péfti páno sto } \\
\text { trapézi }\end{array}$ & The light falls on the table \\
\hline $\begin{array}{l}\text { 'to lose a position } \\
\text { of power or surrender' }\end{array}$ & I diktatoría epese & The dictatorship has fallen \\
\hline $\begin{array}{l}\text { 'detachment } \\
\text { (metaphorical)' }\end{array}$ & @a pésun kefálja & $\begin{array}{l}\text { Heads will fall [i.e. } \\
\text { Someone will be fired] }\end{array}$ \\
\hline 'detachment' & Ta fterá tu puljú épesan & The bird's feathers fell off \\
\hline 'fit' & Tu péfti kalá to padelóni & The trousers fits him well \\
\hline $\begin{array}{l}\text { 'dash, fall violently } \\
\text { on (metaphorical)' }\end{array}$ & Me ton érota péftis sti fotjá & $\begin{array}{l}\text { When it comes to love, } \\
\text { you fall into the fire }\end{array}$ \\
\hline $\begin{array}{l}\text { ' crashing down } \\
\text { on (metaphorical)' }\end{array}$ & $\begin{array}{l}\text { Ta tíxi tu paljú katestiménu } \\
\text { ðen péftun éfkola }\end{array}$ & $\begin{array}{l}\text { The walls of the old } \\
\text { establishment do not fall } \\
\text { easily }\end{array}$ \\
\hline 'tease' & $\begin{array}{l}\text { Afú epiménis na mu } \\
\text { tin péftis étsi, } \theta \text { a ta } \\
\text { apokalípso óla }\end{array}$ & $\begin{array}{l}\text { Since you keep up teasing/ } \\
\text { annoying me, I will reveal } \\
\text { everything }\end{array}$ \\
\hline 'surprise (and catch)' & Tus épiase o eforiakós & $\begin{array}{l}\text { They were caught by the } \\
\text { taxman }\end{array}$ \\
\hline
\end{tabular}

${ }^{17}$ Other collocates in subject position: omíxli ‘fog', skotáði ‘darkness'. 